\title{
Engineering Construction Management in the Countries along One Belt One Road: A Case Study of Pakistan
}

\author{
Fatima Batool ${ }^{1 *}$, Shuhai Zhang ${ }^{1 *}$, Muhammad Abubakar Saddiq ${ }^{2}$, Chengkun $\mathrm{Wu}^{3}$ \\ ${ }^{1}$ School of Public Administration, Renmin University of China, Beijing, China \\ ${ }^{2}$ School of Computer Sciences and Engineering, Beihang University, Beijing, China \\ ${ }^{3}$ Guangzhou College of Technology and Business, Guangzhou, China \\ Email: *fatimabatool.pervez@gmail.com, *zhangshuhai@ruc.edu.cn
}

How to cite this paper: Batool, F., Zhang, S.H., Saddiq, M.A. and Wu, C.K. (2019) Engineering Construction Management in the Countries along One Belt One Road: A Case Study of Pakistan. Open Journal of Business and Management, 7, 1395-1411. https://doi.org/10.4236/ojbm.2019.73096

Received: June 10, 2019

Accepted: July 23, 2019

Published: July 26, 2019

Copyright $\odot 2019$ by author(s) and Scientific Research Publishing Inc. This work is licensed under the Creative Commons Attribution International License (CC BY 4.0).

http://creativecommons.org/licenses/by/4.0/

\begin{abstract}
The purpose of this study is to recognize the key issues in engineering construction management (ECM) under OBOR in Pakistan, to assess their impact on success of ECM projects and to draw suggestions about solutions to these issues. Three major issues named as "time-related issues, budget-related issues and employee-related issues" are recognized in ECM projects and then their impact on success of ECM projects is assessed. Data were collected from $202 \mathrm{CPEC}$ officials through structured questionnaire and analysis was run to check the hypotheses of current study. The findings revealed that there is significant negative impact of employee-related issues, budget-related issues and time-related issues on the ECM project success as these issues create different managerial problems in projects, which causes delay the completion of projects and hampers the success of projects. The solution of these problems is provided in current study. This study is first of its type that has identified and analyzed these three key issues in ECM projects under OBOR in Pakistan in terms of their effect on success of those projects. The current study has noteworthy implications in theoretical and practical terms.
\end{abstract}

\section{Keywords}

Engineering Construction Management, One Belt One Road, China-Pakistan Economic Corridor, Pakistan

\section{Introduction}

A new development in the economic and region of South Asia has so far been witnessed by the 21st century. Projects like CPEC and OBOR have opened up 
the ways for South Asians and another region to tie knots with each other. The current era demands strategic collaborations since the nations cannot cope the current challenges because of tight curbs. Construction managers play a key part in displaying the industry victory and adequacy. The victory of a venture and construction commerce is exceedingly impacted by the abilities connected by development directors. The abilities that a development chief can bring to a company decide the extreme victory of its commerce and its ventures [1]. The parts and duties of construction supervisors are exceptionally comparable in nature all through the world. The engineering construction management scheme scope is known to be the spirit of the scheme by maximum number investigators [2]. [3] suggested that the engineering construction management project possibility is the part of the scheme preparation that comprises recording and defining the list of centric features, aims, goals, and objectives. So on exertion in relations with finances [4] manpower and time need to be put into the engineering construction management project measured by the project scope in the shape of deliverable [5]. Nevertheless, a scheme scope might not be the informal part of the scheme organization.

Time is regarded as essential element in each and every type of project especially when construction management projects are concerned. Human resource is considered as one of the most important resources for progress of any company or organization. Talented and hardworking employees are said to be the backbone of the project. The scope of project is mainly based on the budget. The more the budget is, the more the worth of project is. Budget can help managers and administrators keep the project running. Therefore, the researcher have tried to address cost of the projects, their engendering layout, communication, challenges faced during one belt one road construction and implementation in Asia specifically with the context of Pakistan; all these elements discussed are regarded as vital by the researchers for the success of an engineering construction management project and in the projects like OBOR or CPEC the inclusion and consideration of these will prove to be a success not only for China and $\mathrm{Pa}$ kistan but also for other Asian countries as well [2]. Both the CPEC and OBOR are the projects undertaken by China for expanding the world trade and becoming more strategically active in the world economy [6]. Some strong steps were further taken in 2013 by the Chinese government in the shape of CPEC [7]. The expansion of OBOR or "One Belt One Road" concept from just being the land or maritime Silk Road of the project of CPEC was initiated. Pakistan has been the center of China in order to connect with the regions of Central Asia, South Asia, Middle East and Asia [8]. The port of Gwadar [9] proposes the best suitable routes to China for carrying trade in the Indian region. The project was partly operational in 2016 with the worth of 63 billion US \$. With this project, many of the infrastructural developments and betterments in the transportation and energy sector are expected [7]. When the project will be operational it would have many positive implications for the people and economy of South Asia as estimated by the international media and experts [8]. A great amount of litera- 
ture is available related to OBOR, CPEC and implications of these for Pakistan, China, and other countries also, however, the element of engineering construction management in countries along One Belt One Road has not been discussed by any of the researchers especially in the context of Pakistan. A revolutionary project of OBOR, which is CPEC, is under process in Pakistan and can have the significant impact on the economy of Pakistan but the area of engineering construction management has not been discussed in the literature by the previous researchers, therefore, this study is undertaken to address this issue.

Apparently, both the projects have many opportunities and the advantages for connected nations with respect to engineering construction management project but there could be some unconstructive things about the projects. However, the harmful aspects of OBOR and CPEC in the context of engineering construction management have never been given the due consideration in literature because of which the study would also discuss the disparities of the projects as well. Though the experts have written many articles or news editorials regarding the connection of CPEC, OBOR and the south Asian countries in these studies the engineering construction management is mentioned jointly not separately for each country. Therefore, this study would discuss the separate implications. Pakistan and India are neighboring countries which are also involved in this project but usually there is a tension between the boundaries lines of both nations for a lot of reasons more specifically the Kashmir issue. China is sharing its boundary with both of these but diplomatic relations between Pakistan and China are good as compared to relations with India. Therefore, a sense of un-involvement is usually noticed by India. Time delay, budget issue as well as unemployment can be seen as the problems for construction management projects. Time delay can cause fatal problems in more than one project as most of the times, project is followed by a queue of projects. Also it can directly or indirectly affect the worth of project. Budget can increase of decrease as affected by time constrains. This can be avoided if proper planning and budgeting are done by the experienced employees.

The objectives of the study are as follows:

- To identify the issues, the problems concerning engineering construction management performance for one or more projects under One Belt One Road (OBOR) in Pakistan.

- To list down the possible reasons of the problems identified in the first.

- To check out feasible solutions and recommend them to authorities for action.

The research questions for the study are given below that are to be addressed in this study.

- What are the problems regarding engineering construction management performance for projects under One Belt One Road (OBOR) in Pakistan?

- What are the reasons behind the problems regarding engineering construction management performance for projects under One Belt One Road (OBOR) in Pakistan? 
- What are the possible solutions for solving the problems regarding engineering construction management performance for projects under One Belt One Road (OBOR) in Pakistan?

The study has its importance in many terms. Both the projects are considered capable of making a difference in the region and in the overall world (Ranjan, 2015). As Pakistan is a neighboring country of China, therefore, this has greater importance for China due to which the current economic giant wants the country to be in a peace condition and become an important part of these projects. In such conditions, the study is likely to analyze that what China offers to Pakistan in terms of engineering construction management. On the other hand, the study has its practical significance as well.

Through the scope, the boundary wall of the study is to be defined. In the research studies, it is always important to keep in mind the borderline of the study beyond which the study parameter should not go. Firstly, the scope is related to the research method. The title states that it is a quantitative study where the data in the numeric form is to be collected. For this purpose, the information regarding the One Belt One Road (OBOR) and China Pakistan Economic Corridor (CPEC) projects along with the engineering construction are to be collected through the and analysis of the views presented by different experts. In the quantitative study, some of the graphs could be shown and tests would be applied for having the numeric results. On the other hand, the title states the engineering construction management of One Belt One Road (OBOR) and China Pakistan Economic Corridor (CPEC) projects would only be discussed. After this, the next scope or the boundary line is also provided by the topic of the research study. In the topic of the research study, it is mentioned that the engineering construction management of the One Belt One Road (OBOR) and China Pakistan Economic Corridor (CPEC) projects is to be studied for Pakistan only.

\section{Literature Review}

\subsection{Background}

In the era of Musharraf first time, this economic corridor vision introduced by both countries China and Pakistan [10]. For many years both countries people think about this idea then in May 2013 premiere of China Mr. Li Keqiang came in Pakistan and during his Pakistan visit he raised the importance of CPEC project and said construction should be made on this project. In May landmark CPEC project is signed between Pakistan and China [11]. Then Pakistan Prime Minister Muhammad Nawaz Sharif visited China and there are eight agreements signed at that time which cost was 18 billion dollars. In those agreements, it was decided that $200 \mathrm{~km}$ route will be built in CPEC project. Then in 2014 the Pakistan president Mamnoon Husain went to China and both countries make discussion on CPEC project. Then again Nawaz Sharif went to China and almost nineteen agreements signed by both countries [11]. Then they estimated the cost of the CPEC project which is 46 billion dollars and explained the strategic im- 
portance of CPEC for both Pakistan and China [10]. Then on 20 April 2015 president of China Xi Jinping came in Pakistan and launch the CPEC project. In the history of Pakistan, almost two times Chinese president came to Pakistan first time in 2006 Chinese president Mr. Hu Jintao's visited Pakistan after that in $2015 \mathrm{Xi}$ visited Pakistan. In $2014 \mathrm{Xi}$ visit to Pakistan canceled due to unstable political and economic condition in Pakistan. Xi signed 51 agreements with $\mathrm{Pa}$ kistan included energy, transport, Gwadar and others agreements. These agreements cost will be 46 billion dollars and divided this cost into small projects [10]. It is a huge investment made by China in Pakistan and that is very impressive. Pakistan never received such huge foreign direct investment amount in past years and not such huge cross-cultural project was developed in Pakistan [12].

In these corridors, two are with the South Asian countries. "China-Pakistan Economic corridor" or CPEC, with 3000-kilometer length has the initial point in Kashgar, the Chinese area, and connects it Gwadar port in Pakistan. Furthermore, the corridor is meant to link the northern areas of One Belt One Road (OBOR) with the maritime Silk Road in South [13]. Additionally, the other corridor in the South Asian country is the "Bangladesh-China-India-Myanmar Economic Corridor" that was also initiated in the year 2013 with the objective of linking the markets of China and India for harvesting the benefits of resources, technology, and labor from both the countries [12].

\subsection{Implications of One Belt One Road (OBOR) for Engineering Construction Management}

The aim of developing positive and strengthened relations with the South Asian countries also exists [10]. The promise of China with these countries related to the development and improvements in the infrastructure, energy, cultural exchange and the movement of labor. Mostly, the developing countries are there in the South Asian region. In this section, the implications of One Belt One Road (OBOR) project in the South Asian region are to be discussed carefully [14]. The engineering construction management is to be considered in all the projects carried out under CPEC, the important corridor of OBOR, therefore, the discussion about each element is given under.

\subsubsection{Energy Sector}

In the energy sector, China has also financed the South Asian countries and among these Pakistan in most apparent. One instance of One Belt One Road (OBOR) project in the South Asian energy sector is in Pakistan where China has invested in a hydropower station. The "Nehru Tim Jielu Mu Hydropower Station" is financed by the initiator of One Belt One Road (OBOR) project for having positive and strategic relations with Pakistan. In the year, the construction of the "Nehru Tim Jielu Mu Hydropower Station" was got approved by the Chinese officials and Chinese engineers who then started the construction of the project. In the project, the "China Gezhouba Group Co., LTD" (CGGC) and the "China Machinery Engineering Corporation" (CMEC) were involved [14]. The reports 
have presented the statistics regarding the financing value of the project according to which China has so far injected about the US $\$ 4.3$ billion in the project. The aim is to construct a hydropower station at Nehru River and the produced electricity would cut the shortfall to a significant level giving the economy of Pakistan a boost. Furthermore, the project has been regarded as the biggest hydropower project of Pakistan having the abilities to generate 5.15 Billion kilowatt hour [15]. Through this project, the revival of electricity is possible in Pakistan resulting in the boost as well as the development of the economy. Nevertheless, the negative aspects of these projects have not been discussed in the research studies.

\subsubsection{Dam Construction}

The reports also presented the facts regarding the construction of dams by Chinese companies in Thailand and Vietnam. The projects also have financial backing by the US government under the of One Belt One Road (OBOR) project. The designing strategy of the project has been carried out by the Power China Company. The construction of these dams was started years back and one of the dams was completed in the year 2016 [10]. These dams have been constructed by the Chinese government for export of energy in form of electricity to the countries of Vietnam and Thailand. Furthermore, the China government aspires to deliver energy to the South Asian countries through the chain of 72 dams as it wants to become the "Battery of South Asia" [15]. From the chain of these dams one, namely, Nam Khan 3 hydropower project, opened its gates for the people of the valley in Thailand. The researchers [10], have also pointed out this important implication that through this project of One Belt One Road (OBOR) project the farmers, who are in a larger number in that valley, can grab the opportunities of boosting their yields and through that they can capture the markets of other Countries paving their way for establishing the connections with other South Asian countries in the region. The dam is also a part of engineering construction management that OBOR needs to carefully consider as this would impact Pakistan to a greater extent [16].

\subsection{Problems in Success of Project Construction Management}

There is no project that can be achieved without any hurdle of difficulty, each project has to face some issues that can create difficulty in the success of projects. Those basic problems are time-related issues, employer related issues and budget-related issues.

\subsubsection{Time-Related Issues}

There are many projects that got disturbed just due to mismanagement of the time. As time is the most important element of all types of project. But delay issues can be caused due to many reasons. This time delay is not only dangerous and sign of threat for the person for whom project is going to be made but also for those people who are involved in making this project. These risks can be an 
uncertainty in financial market, hidden flaws in the project plan or unknown factors that can impact the success of a project [17].

\subsubsection{Employer Related Issues}

Many projects are cancelled or disturbed due to employers mainly. As employers are the backbone of every project, if they are active characters of every project then ultimately project can be achieved more efficiently. Likewise, your business suffers when there is no clarity and forethought before starting a project [18]. On the other hand, motivation as well as inspiration also plays a great role in making employees to get involve efficiently in their respective tasks and to do work effectively when there is more work load or there is need to meet the deadline early. As a result, employers should not be ignored as only with them project or goal can be achieved.

\subsubsection{Budget-Related Issues}

One more major issue which is mostly faced in making or constructing project is the heavy as well as uneven budget. Resources including balanced budget have great importance [19]. Corrective actions need to be consulted with the project team and the staff in charge of the activities so that changes are implemented" [20].

\subsection{Time-Related Issue and Engineering Construction Management Success}

It is considered that time-related issues have a great impact on success of engineering construction management as it time delays then it creates more costs for the project managers or the owners to bear as due to delayed projects, expenses got increase and ultimately projects got expensive that can create issues on the outcome of the project in the form of failure in project. In one research it was recommended that, "Delays are frequently reported as the cause of several conflicts that affect the different parties involved in construction projects. In order to avoid these conflicts and succeed on the delivery of construction projects, contractors should implement project management processes. Project management includes a number of planning and controlling processes that are recommended for complying with the owners' requirements related to project time, cost, quality, and others" [21].

\subsection{Employer Related Issue and Success in Engineering Construction Management}

Employers that are considered to be the most important part of the project need to be active in all types of project whether they are related to construction or any other type of project. The ability to engage sub-contractors who are known and trusted would take a lot of the stress and learning curve away from the constructor manager, but procurement rules often force him to develop a whole new relationship on every project [22]. As if some issues take place then it can be 
communicated well within time and can be resolved without any delay, for this reason, communication has a great importance in any task. In one more place, it was observed that, "Miscommunication with the labor force on site. Poorly educated, unskilled labor will generally be eager to please and not ask questions if they do not understand instructions. This is exacerbated if the staff is foreign" [22]. In one more research, it was revealed that if employees are treated well and are motivated in their work then they perform in a more perfect way then that situation in which there is no incentive and motivation for employees as otherwise it will create issues related to employees and will create failure in the success of construction project [23].

\subsection{Budget-Related Issues and Success in Engineering Construction Management}

It is observed that before making any project, it is necessary to manage the cost and expenses by forecasting and pre planning as without forecast and pre plan thee will be no successful outcome in the project as there will be no arrangement of resources as well as capital to continue or start the project. As monitored and controlled cost make project managers able to have full authority on solution resolutions during the process or procedures of project [24]. Preplanning is necessary as it makes able the project manager to compare forecasted budget and actual budget in every step, so that project manager can evaluate both budgets at every step and can resolve the matter if there is any issue in the process of managing the cost in the construction.

\subsection{Theoretical Framework}

The purpose of this study is to investigate the relationship between time-related issues, employees-related issue, and budgeted related issues as independent and their impact engineering construction management success as dependent variables (Figure 1).

\section{Hypotheses}

$H 1$ : Time-related issues have significant relation with engineering construction management for Pakistan under OBOR.

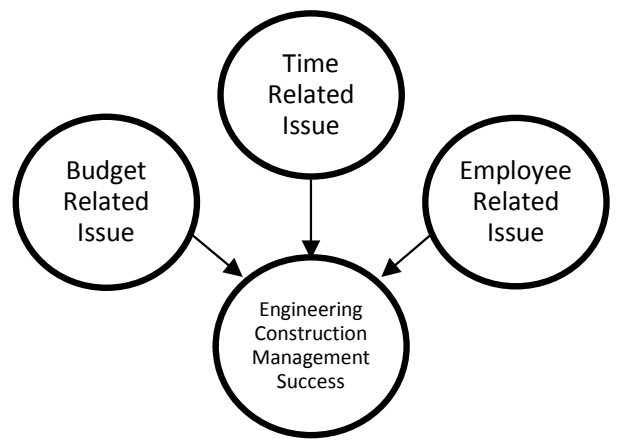

Figure 1. Theoretical framework. 
Time constrain is considered to be one essential factor, as scope and worth of whole project and many others behind it depends on this factor. Therefore, it cannot be neglected at any cost.

H2: Employee-related issues significantly impact the engineering construction management for Pakistan under OBOR.

Employment of skillful and hardworking workers can take the standard of project higher. Inversely, if workers are not dedicated and motivated, the project may get delayed, resulting in increment of budget

$H 3$ : Budget-related issues have significant relation with engineering construction management for Pakistan under OBOR.

If proper planning is done and resources such as human resource and budget are allocated in a fashionable manner that no such issue is observed, the project can make progress by leaps and bounds, if one or more factors are allocated in wrong way, it can ruin the objective of project.

\section{Methodology}

In the present study, the positivism philosophy appropriated on the base of study nature, because the purpose of this study is to investigate the relationship between time-related issues, employees-related issue, and budgeted related issues as independent and their impact engineering construction management success as dependent variables with quantitative data. Moreover, the role of the researcher in this study is as an independent person, and the study emphasized on "What is" rather than "what or how should be". This study collects the data in quantifiable forms in order to investigate the relationship between variables which are proposed and various statistical tests are used to draw the conclusions about engineering construction management under OBOR in the context of Pakistan.

\section{Results and Discussion}

\subsection{Demographic Analysis}

In demographic analysis, the demographic features of respondents of study are analyzed. In current study, three demographic features named as age. Gender and experience were assessed. It's a relation between population size $\mathrm{N}$ and sample size $\mathrm{n}$ and confidence interval $\mathrm{L}$. The results regarding frequency and proportion of each demographic characteristic in sample have been displayed in Table 1 .

The sample size is 202 therefore, the $\mathrm{N}=202$. It means that the analysis has been performed with total 202 observations. The results provided in Table 1 are showing a complete picture of demographic analysis of current data. The demographic of gender was assessed by asking about the gender of respondents in the questionnaire. It is found that major portion of the sample consisted of males as there were 74.8 percent males in sample while the proportion of females in the sample was only 25.2. This is because most of the working official in CPEC con- 
struction management are males in Pakistan therefore, the representation of males in the sample is more than that of females. The demographic of age and results against it found in current study depict that major portion of sample was having the age between 21 to 50 years. This is because there are officials of almost every age in CPEC construction management. The respondents having age ranging from 21 to 30 and ranging from 41 to 50 were $29.7 \%$ and $28.2 \%$ that is almost the same proportion however, most of the respondents were of age falling between 31 - 40 because 37.6 percent respondents reported their age in this category. The respondents with age more than 50 years were very few as only $4.5 \%$ respondents were such who were having age more than 50 years. While looking at the results of demographic analysis against experience, it is clear from the results that major portion of sample has the experience ranging from 2 years to 8 years because 40.6 percent respondents reported their experience falling in the range of 2 - 5 years and 39.6 percent respondents reported it falling in range of 5 to 8 years. The experience less than 2 years got few responses (i.e. 8.9\%). The respondents having experience more than 8 years were also few in numbers because only $10.4 \%$ respondents reported their experience as "more than 8 years". The overall demographic analysis depicts that most of officials in construction management under CPEC are of moderate age, have good experience and are males because proportion and representation of these categories were high in sample of study as well. Most software for regression can achieve robustness check.

\subsection{Descriptive Statistics}

The descriptive analysis is run to check the adequacy and normality of data normally in which the mean value, minimum value, maximum value, skewness and kurtosis are normally checked to assess the adequacy of data. To check the normality and adequacy of current data, same analysis was run and results found against those tests have been displayed in Table 2 .

Table 1. Demographic characteristics $(\mathrm{N}=202)$.

\begin{tabular}{cccc}
\hline Characteristic & Category & Frequency & Percentage \\
\hline \multirow{2}{*}{ Mender } & Female & 151 & 74.8 \\
Age & 20 - 30 years & 51 & 25.2 \\
& $31-40$ years & 60 & 29.7 \\
& 41 - 50 years & 76 & 37.6 \\
& Above 50 years & 57 & 28.2 \\
Experience & Less than 2 year & 9 & 4.5 \\
& $2-5$ years & 18 & 8.9 \\
& 5 - 8 years & 80 & 40.6 \\
& More than 8 years & 21 & 39.6 \\
& & & 10.4 \\
\hline
\end{tabular}


Table 2. Descriptive statistics $(\mathrm{N}=202)$.

\begin{tabular}{|c|c|c|c|c|c|c|c|}
\hline & \multirow{2}{*}{$\begin{array}{c}\mathrm{N} \\
\text { Statistic }\end{array}$} & \multirow{2}{*}{$\begin{array}{c}\text { Minimum } \\
\text { Statistic }\end{array}$} & \multirow{2}{*}{$\begin{array}{c}\text { Maximum } \\
\text { Statistic }\end{array}$} & \multirow{2}{*}{$\begin{array}{c}\text { Mean } \\
\text { Statistic }\end{array}$} & \multirow{2}{*}{$\begin{array}{c}\text { Std. Deviation } \\
\text { Statistic }\end{array}$} & \multicolumn{2}{|c|}{ Skewness } \\
\hline & & & & & & Statistic & Std. Error \\
\hline ERI & 202 & 1.00 & 4.80 & 3.7505 & 0.81205 & -0.086 & 0.171 \\
\hline BRI & 202 & 1.00 & 5.00 & 3.8673 & 0.90495 & -0.266 & 0.171 \\
\hline TRI & 202 & 1.00 & 5.00 & 3.8871 & 0.93081 & -0.300 & 0.171 \\
\hline $\begin{array}{c}\text { ECM Project } \\
\text { Success }\end{array}$ & 202 & 1.00 & 5.00 & 2.1139 & 0.84181 & 0.528 & 0.171 \\
\hline
\end{tabular}

The results of descriptive analysis show that mean value for the variable of employee-related issues (ERI) The minimum and maximum value of Budget-related issues (BRI), time-related issues (TRI) and ECM project success are all falling between the ranges of 1 to 5 that was the rating scale used in the questionnaire for these variables. It means that there is no extreme value in the data of any variable so there is no outlier in data and the data is normally distributed. The mean values for these variables are also adequate and within the range respectively that showing that range of data is normal and there is no outlier in the data of ERI, BRI and TRI because the minimum and maximum values are between 1 to 5 that was the rating scale of variable. To assess the normality of data, the skewness of all variables is checked which should always range from -1 to +1 for normal data. The skewness of ERI, BRI and TRI is which is definitely within the range of -1 to +1 so normality in the data od ERI is ensured. The overall descriptive analysis is showing that current data is adequate and normal and further analysis can be proceeded with current data because it is able to be analyzed in its current form.

\subsection{Reliability Test}

The reliability of data is assessed to check whether the items measuring a variable are measuring that particular variable reliably or not. To check the reliability, a very important indicator is Cronbach's alpha. The Cronbach's alpha depicts the reliability of variables and it should be equal to or more than 0.7 to ensure the reliability. The value of this indicator against each of current variables was generated through analysis. The Cronbach's alpha value for ERI, BRI, TRI and ECM project success have been presented in Table 3.

The Cronbach's alpha value for five items of ERI, BRI and TRI which is $>0.7$ so, the reliability is ensured and it is found that five item scale of ERI, BRI and TRI currently used is reliable. Therefore, it is found through reliability test that all current scales and variables are reliable and adequate so these scales and data against them can be further used in analysis of current model and hypotheses.

\subsection{Correlation Test}

The correlation test is used to assess the correlated between variables for which the Pearson correlation indicator is one of the best indicators. The correlation 
results determine that what type of correlation two variables have between them and what is the strength of that relationship. The Pearson correlation test was run for current data and the values against each variable and relationship were found along with their significant values. The results of correlation have been displayed in Table 4.

The results of Pearson correlation of each variable against its own variables are showing that each variable is perfectly correlated with itself as the correlation value of each variable with itself is 1 . The correlation of each variable with itself is more than its correlation with any other variable. It is confirming the discriminant validity of all variables. The correlation of employee-related issues with the ECM project success is -0.854 that is showing that ERI is negatively correlated with success of ECM project. It means that ERI and ECM project success are inversely related. With increase in one variable, the other variable decreases. This correlation is significant at $\mathrm{P}$ value less than 0.01 . The correlation of BRI with the success of ECM project is -0.892 , which is again showing the negative correlation between BRI and ECM project success. This correlation is also significant at $\mathrm{P}$ value less than 0.01 . The Pearson correlation value of TRI with ECM project success is -0.883 , which means that TRI is negatively correlated

Table 3. Reliability results $(\mathrm{N}=202)$.

\begin{tabular}{ccc}
\hline Variables & No. of Items & Cronbach's $\alpha$ value \\
\hline Employee-related issues & 5 & 0.908 \\
Budget-related issues & 5 & 0.930 \\
Time-related issues & 5 & 0.941 \\
ECM project success & 6 & 0.934 \\
\hline
\end{tabular}

Table 4. Correlations.

\begin{tabular}{|c|c|c|c|c|c|}
\hline & & ERI & BRI & TRI & ECM Project Success \\
\hline \multirow{3}{*}{ ERI } & Pearson Correlation & 1 & $0.882^{* *}$ & $0.853^{* *}$ & $-0.854^{* *}$ \\
\hline & Sig. (2-tailed) & & 0.000 & 0.000 & 0.000 \\
\hline & $\mathrm{N}$ & 202 & 202 & 202 & 202 \\
\hline \multirow{3}{*}{ BRI } & Pearson Correlation & $0.882^{* *}$ & 1 & $0.900^{* *}$ & $-0.892^{* *}$ \\
\hline & Sig. (2-tailed) & 0.000 & & 0.000 & 0.000 \\
\hline & $\mathrm{N}$ & 202 & 202 & 202 & 202 \\
\hline \multirow{3}{*}{ TRI } & Pearson Correlation & $0.853^{* *}$ & $0.900^{* *}$ & 1 & $-0.883^{* *}$ \\
\hline & Sig. (2-tailed) & 0.000 & 0.000 & & 0.000 \\
\hline & $\mathrm{N}$ & 202 & 202 & 202 & 202 \\
\hline \multirow{3}{*}{$\begin{array}{c}\text { ECM Project } \\
\text { Success }\end{array}$} & Pearson Correlation & $-0.854^{* *}$ & $-0.892^{* *}$ & $-0.883^{* *}$ & 1 \\
\hline & Sig. (2-tailed) & 0.000 & 0.000 & 0.000 & \\
\hline & $\mathrm{N}$ & 202 & 202 & 202 & 202 \\
\hline
\end{tabular}

${ }^{* *}$ Correlation is significant at the 0.01 level (2-tailed). 
with success of ECM project. The P-value against this correlation of TRI and ECM project success is $<0.01$. The overall correlation results show that Pearson correlation of all variables is $>-0.3$ (i.e. threshold value) showing strong negative correlation so, the ERI, BRI and TRI have significant negative correlation with success of ECM project.

\subsection{Regression Analysis}

The current study produced the results against ANOVA, model summary and coefficients to accept or reject hypotheses of current study. The results of model summary have been presented in Table 5 that is showing R square and adjusted $\mathrm{R}$ square value for current model.

The table of model summary depicts that the current model with independent variables of TRI, BRI and ERI and with reliant variable of ECM project success is fit because adjusted $\mathrm{R}$ square value for this model is 0.836 , which is satisfactory and acceptable. It means that more than 50 percent (i.e. 83.6\%) variation in dependent variable (i.e. ECM project success) is explained by the independent variables of current study that are TRI, BRI and ERI. Thus, the current model is adequate and fit for regression. Besides summary, the current analysis also includes the ANOVA results found against current data and variables as given in Table 6.

The table of ANOVA depicts the significance of regression results. For significance of results, the F value should be more than F tabulated or than 4 and significance level should be less than 0.05. The current ANOVA table is showing that value of $\mathrm{F}$ is 342.843 , which is $>4$ and $\mathrm{P}$ value for these results is less than 0.05 thus, the results of regression are significant for current model. Finally, the coefficients are found of each relationship included in current model. The resulting values of coefficients have been displayed in Table 7 .

The results of coefficients show that there is significant negative impact of ERI on ECM project success with coefficient size of -0.217 . It means that with one-unit increase in ERI, there is decrease of $21.7 \%$ in ECM project success ( $P$ value $<0.05$ ). The impact of BRI on ECMPS is also negative and significant at $\mathrm{P}$ value less than 0.05 . The coefficient size for this impact is -0.355 , which means that with one percent increase in BRI, there is $35.5 \%$ decrease in dependent variable. TRI also showed negative impact on ECM project success with significant level $(<0.05)$. The coefficient size for this effect is -0.327 that is showing that one percent increase in TRI causes $32.7 \%$ decrease in ECM project success. Hence, all three hypotheses of current study are accepted based on significant results.

Table 5. Model Summary.

\begin{tabular}{ccccc}
\hline Model & $\mathrm{R}$ & R Square & Adjusted R Square & Std. Error of the Estimate \\
\hline 1 & $0.916^{\mathrm{a}}$ & 0.839 & 0.836 & 0.34078 \\
\hline
\end{tabular}

apredictors: (Constant), TRI, ERI, BRI. 
Table 6. ANOVA Results.

\begin{tabular}{ccccccc}
\hline \multicolumn{1}{c}{ Model } & Sum of Squares & df & Mean Square & F & Sig. \\
\hline \multirow{3}{*}{1} & Regression & 119.443 & 3 & 39.814 & 342.843 & $0.000^{\mathrm{b}}$ \\
& Residual & 22.994 & 198 & 0.116 & & \\
& Total & 142.437 & 201 & & & \\
\hline
\end{tabular}

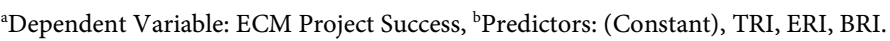

Table 7. Coefficients.

\begin{tabular}{|c|c|c|c|c|c|c|}
\hline & \multirow{2}{*}{ Model } & \multicolumn{2}{|c|}{ Unstandardized Coefficients } & \multirow{2}{*}{$\frac{\text { Standardized Coefficients }}{\text { Beta }}$} & \multirow{2}{*}{$\mathrm{t}$} & \multirow{2}{*}{ Sig. } \\
\hline & & B & Std. Error & & & \\
\hline \multirow{4}{*}{1} & (Constant) & 5.572 & 0.114 & & 48.796 & 0.000 \\
\hline & ERI & -0.217 & 0.066 & -0.209 & -3.308 & 0.001 \\
\hline & BRI & -0.355 & 0.070 & -0.382 & -5.049 & 0.000 \\
\hline & TRI & -0.327 & 0.062 & -0.361 & -5.293 & 0.000 \\
\hline
\end{tabular}

${ }^{a}$ Dependent Variable: ECM Project Success.

The current study aimed to recognize the major problems and issues in construction management projects that can hamper the success of these projects under OBOR. There is negative significant impact of TRI on ECM project success. These findings of current study are much aligned with past studies and their results. [21] also suggested the negative association of TRI with success of construction projects. [25] also reported the significant association and dependence between time-related issues and success or failure of projects. In response to the second hypothesis of current study i.e. "Employee-related issues significantly impacts the engineering construction management for Pakistan under OBOR", the current findings suggested the acceptance of this hypothesis. It is reported and suggested through findings that there is significant negative impact of ERI on success of ECM projects. It means that when there is employee-related issues and conflicts in the project then project is likely to face failure. The results of current study regarding employee-related issues and their negative impact on success of project are in line with previous researchers' results e.g. [22] also reported the significant association of ERI with the success of construction project. The research work of [23] is also found as a supporting study for current results because they also suggested that when there is increased employee-related issues in the projects then there are more chances of failure of projects and decreased chances of its success. It is suggested that conflicts related to employees should also be managed properly by communication and collaborations. The third hypothesis of current study i.e. "Budget-related issues have significant relation with engineering construction management for Pakistan under OBOR" is also accepted and it is found that BRIs have negative significant impact on success of EC projects. The findings of current research are much aligned with past findings e.g. the work and findings of [24] are also in line with current findings as 
they suggested that when project managers are able to effectively control and manage cost and budget of project then projects are very likely to succeed. The project managers should necessarily manage the cost and budget issues effectively in order to enhance the success chances of projects [17]. In addition to the cost and budget management, another effective way to solve such issues is the evaluation system.

\section{Conclusions}

The current study was about the identification of major issues in construction management, analyzing their influence on success or failure of projects and then suggestion solution for those issues. The current study assessed the three key issues named as employee-related issue, budget-related issues and time-related issues; and checked the impact of these issues on the success of ECM projects by collecting data from CPEC officials and running regression on collected data. All the hypothesis of current study was accepted and the results revealed the negative impact of all these three issues on the success of ECM projects. All these findings are in line with previous results and supported through those findings evidently. The current study has significant implication in theoretical and practical terms.

\subsection{Implications}

For the theoretical implications, this study did test the relationship between time-related issues, budget-related issues, employees-related issues and engineering construction companies' success in project of OBOR in a new context which is the CPEC project of Pakistan and China. It was proved to be effective. Therefore, this study contributes to prior literature with new finding and data. Moreover, results also indicated the benefits of CPEC which eventually leads the assistances or the inferences of the China Pakistan Economic Corridor in South Asia. For policy recommendations, it is proceeding from the findings of this study. Since CPEC aggressively and continuously working in Pakistan and China, the concern department and government should provide incentives for research and development to researchers who would continue to invest their time and skills in discovering more innovations regarding CPEC. It is recommended that the concern department also pursues a strategy to provide incentives for technology transfer from more developed countries in order to promote the adoption of world class. It is helpful for the government such as the newly government of Pakistan working for the attraction of international investor into CPEC.

\subsection{Limitation and the Future Indication}

There are several limitations which are faced by the study that should be taken into account. First, the sample size of the study is limited due to constrained time. The researcher has only four months to complete the entire process of the 
study. Second, this study based on Pakistan and data only collected from the officials and workmen who are involved in the OROB project which is the part of CPEC. Third, this study collected data only one time by using the cross-sectional method. Fourth, this study used only three estimators i.e., time-related issues, employees-related issues and budget-related issue. Since CPEC is still a relatively new phenomenon with few studies which are investigating the different actors involved in it, the researcher recommends that further and extended research be carried out in order to come up with more findings that this study may not have been able to reveal. First, sample size can be increased and the data can be collected from more aspect regarding construction and other CPEC project. Secondly, the replication of this study can be made by using same or qualitative approach and longitudinal collection method.

\section{Conflicts of Interest}

The authors declare no conflicts of interest regarding the publication of this paper.

\section{References}

[1] Ahmed, R. and Mustafa, U. (2014) Impact of CPEC Projects on Agriculture Sector of Pakistan: Infrastructure and Agricultural Output Linkages. Pakistan Institute of Development Economics (PIDE), Islamabad.

[2] Kramar, R. (2014) Beyond Strategic Human Resource Management: Is Sustainable Human Resource Management the Next Approach? The International Journal of Human Resource Management, 25, 1069-1089. https://doi.org/10.1080/09585192.2013.816863

[3] Rees, G. and Smith, P. (2017) Strategic Human Resource Management: An International Perspective. Sage, Thousand Oaks.

[4] Ritzinger, L. (2015) The China-Pakistan Economic Corridor. Regional Dynamics and China's Geopolitical Ambitions. The National Bureau of Asian Research, Washington DC.

[5] Senaratne, S. and Ruwanpura, M. (2016) Communication in Construction: A Management Perspective through Case Studies in Sri Lanka. Architectural Engineering and Design Management, 12, 3-18. https://doi.org/10.1080/17452007.2015.1056721

[6] Adams, O.P. and Carter, A.O. (2010) Diabetes and Hypertension Guidelines and the Primary Health Care Practitioner in Barbados: Knowledge, Attitudes, Practices and Barriers-A Focus Group Study. BMC Family Practice, 11, 96. https://doi.org/10.1186/1471-2296-11-96

[7] Haq, R. and Farooq, N. (2016) Impact of CPEC on Social Welfare in Pakistan: A District Level Analysis. In: Proceedings of the 32 nd Annual General Meeting and Conference, Pakistan Society of Development Economics, Pakistan Institute of Development Economics, Islamabad, 1-33.

[8] Llanto, G.M. (2012) The Impact of Infrastructure on Agricultural Productivity. PIDS Discussion Paper Series.

[9] Saqib, D., Masnoon, M. and Rafique, N. (2013) Impact of Foreign Direct Investment on Economic Growth of Pakistan.

[10] Aqeel, M. (2016) Impact of China Pakistan Economic Corridor. Unpublished De- 
gree Thesis, BBA International Business, ARCADA.

[11] Shaikh, F., Ji, Q. and Fan, Y. (2016) Prospects of Pakistan-China Energy and Economic Corridor. Renewable and Sustainable Energy Reviews, 59, 253-263. https://doi.org/10.1016/j.rser.2015.12.361

[12] Abid, M. and Ashfaq, A. (2015) CPEC: Challenges and Opportunities for Pakistan. Journal of Pakistan Vision, 16, 142-169.

[13] Javaid, U. and Javaid, R. (2016) Strengthening Geo-Strategic Bond of Pakistan and China through Geo-Economic Configuration. Pakistan Economic and Social Review, 54, 123.

[14] Small, A. (2015) The China-Pakistan Axis: Asia's New Geopolitics. Oxford University Press, Oxford. https://doi.org/10.1093/acprof:oso/9780190210755.001.0001

[15] Bhattacharjee, D. (2017) China Pakistan Economic Corridor (CPEC) Indian Council of World Affairs.

[16] Khan, Z.H., Alin, T.S. and Hussain, M.A. (2011) Price Prediction of Share Market Using Artificial Neural Network (ANN). International Journal of Computer Applications, 22, 42-47. https://doi.org/10.5120/2552-3497

[17] Marsh, P. (2017) Contracting for Engineering and Construction Projects. Routledge, Abingdon-on-Thames. https://doi.org/10.4324/9781315259369

[18] Demirkesen, S. and Arditi, D. (2015) Construction Safety Personnel's Perceptions of Safety Training Practices. International Journal of Project Management, 33, 1160-1169. https://doi.org/10.1016/j.ijproman.2015.01.007

[19] Kivilä, J., Martinsuo, M. and Vuorinen, L. (2017) Sustainable Project Management through Project Control in Infrastructure Projects. International Journal of Project Management, 35, 1167-1183. https://doi.org/10.1016/j.ijproman.2017.02.009

[20] Zhang, J. and Xu, L. (2015) Embodied Carbon Budget Accounting System for Calculating Carbon Footprint of Large Hydropower Project. Journal of Cleaner Production, 96, 444-451. https://doi.org/10.1016/j.jclepro.2013.10.060

[21] Maqsoom, A., Khan, M.U., Khan, M.T., Khan, S. and Ullah, F. (2018) Factors Influencing the Construction Time and Cost Overrun in Projects: Empirical Evidence from Pakistani Construction Industry. In: ChauIsabelle, K.W., Chan, Y.S., Lu, W. and Webster, C., Eds., Proceedings of the 21 st International Symposium on Advancement of Construction Management and Real Estate, Springer, Berlin, 769-778. https://doi.org/10.1007/978-981-10-6190-5_69

[22] Naoum, S.G. (2016) Factors Influencing Labor Productivity on Construction Sites: A State-of-the-Art Literature Review and a Survey. International Journal of Productivity and Performance Management, 65, 401-421. https://doi.org/10.1108/IJPPM-03-2015-0045

[23] Becker, K. and Smidt, M. (2016) A Risk Perspective on Human Resource Management: A Review and Directions for Future Research. Human Resource Management Review, 26, 149-165. https://doi.org/10.1016/j.hrmr.2015.12.001

[24] Zou, Y., Kiviniemi, A. and Jones, S.W. (2017) A Review of Risk Management through BIM and BIM-Related Technologies. Safety Science, 97, 88-98. https://doi.org/10.1016/j.ssci.2015.12.027

[25] Loganathan, S., Srinath, P., Mohan, K., Kalidindi, S. and Varghese, K. (2017) Identifying and Addressing Critical Issues in the Indian Construction Industry: Perspectives of Large Building Construction Clients. Journal of Construction in Developing Countries, 22, 121-144. https://doi.org/10.21315/jcdc2017.22.supp1.7 